\title{
Modelling the Potential Accumulation Zones of Surface Current and Wind Driven Particles in the Shoreline of Baltic Sea in Latvia
}

\section{Daiga CEPĪTE-FRIŠFELDE, Aigars VALAINIS, Juris SEN̦N̦IKOVS, Vilnis FRIŠFELDS}

\author{
Institute of Numerical Modelling, Faculty of Physics, Mathematics and Optometry, \\ University of Latvia, Jelgavas street 3, Riga, LV-1004, Latvia \\ daiga.cepite-frisfelde@lu.lv, aigars.valainiselu.lv, \\ jsenniko@latnet.lv, frishfeldsalatnet.lv
}

\begin{abstract}
University of Latvia (UL) has acquired experience in the development of operational oceanographic data visualisation software FiMar for search and rescue purposes since 2004. Free operational object drift forecast service developed by UL is available on: www.water.lv/fimarweb since 2018. Developments benefit from oceanographic model data from Copernicus Marine Environment Monitoring service and operational oceanography Hiromb-BOOS model at UL and marine meteorology data from the Danish Meteorological Institute driven HARMONIE model. Recent experience has shaped the numerical drift experiment: floating particles have been daily released on the surface of the virtual Baltic Sea model and their paths have been analysed. Results show that the coastline of Latvia, which accounts $3.5 \%$ of the coastline in the model, receives $9.3 \%$ of the released particles - illustrating the dominant winds in the region. Seasonality of number of particles washed ashore in Baltic Sea shoreline of Latvia is analysed in the study.
\end{abstract}

Key words: drift modelling, Baltic Sea, fimarweb

\section{Introduction}

"Touched by eternity" - the name that Latvian poet Aleksandrs Čaks gave to the famous collection of epic poems about the World War I included in Latvian Cultural Canon might give the first impressions of the sea. On the brighter side - the sea as reservoir where the food - the fish and seaweeds can be harvested is known as well. Besides fishing and transportation of goods a written evidence in digitized press of Latvia available through online catalogue by National Library of Latvia (www.periodika.lv) mentions that there have been made artificial moles - typically $120-150 \mathrm{~m}$ long and 1.5 $\mathrm{m}$ wide wooden structures that catch the seaweeds in years 1936-1938 in the shoreline of Latvia. The most yield of the seaweeds later used for arable land improvement has been obtained during winter - after the strong autumn storms. The same source of information illustrates the sea washing ashore wooden building materials and other valuable goods from the broken ships, tugboats and rafts in the beginning and middle of 20th century. 
The law regulating the mechanism how and when the washed ashore goods could be used has been mentioned in the press in 30-ies of the 20th century. Nowadays much improvement in the safety on the sea has been done. Huge amounts of the washed ashore goods in the seaside of Latvia remain in history. The rafts are not used in transportation of wooden material anymore. Storm museum has been opened in Jūrkalne in year 2017 - it provides evidence of the underwater heritage and materials washed ashore during the storms in the Baltic Sea shore of Latvia.

Shoreline of the Baltic Sea in Latvia is among the regions - similarly to Lithuania and Kaliningrad - where amber gems could be found in 21 st century. There are no commercial aquaculture sites and offshore wind farms on the shoreline of Latvia until now. The area included in the Ramsar sites bordered by Lithuania at the south - Pape Wetland Complex is one of the important heritage regions of the shoreline of the Baltic Sea in Latvia.

Since operational oceanographic information is used by marine transport sector and search and rescue on the sea, there have been continuous development of the operational oceanographic forecasting systems that produce operational oceanographic forecasts. The increase in data resolution acquired by higher computational power available is characteristic feature of the developments in the field.

In year 2004 visualisation software of operational atmosphere and ocean forecasts for the Baltic Sea was developed by University of Latvia as proprietary information system FIMAR - national operational oceanographic service. Software includes functionality of visualisation, animation, decision support in resource allocation, route planning, search and rescue operations.

In years 2018-2019 Present the present: FiMar for Web: has been developed as freely available operational oceanography and drift forecast service - an example of Copernicus Marine Environment monitoring service data application www.water.lv/present for safety and marine navigation by University of Latvia.

Initially oceanographic information visualised in the FIMAR has been aimed for the search and rescue as well as oil pollution combating operations. Another issue - seas and oceans plastic pollution has attracted the interest of the researchers recently. It has been widely accepted that the plastic pollution (including microplastics) loads in the seas and oceans are among the main issues in ocean research today (Hardesty and Vince, 2016, Villarrubia-Gómez et al. 2018). Marine debris transportation on the sea surface has been broadly investigated in Mediterranean Sea region (Liubartseva et.al. 2018). The problem has been spotted also in Stockholm archipelago in the Baltic Sea (Gewert et al., 2017).

There has been much clearer understanding of the processes impacting the motion of the drifting objects - for example drifting ice in the regions far from the coast than the motion mechanisms close to the shoreline (Uotila, 2001). Washing ashore events are still not fully understood. There exists hypothesis regarding the subject - sea coastal zone under stormy winds might play a role of a mill for plastics, and negatively buoyant pieces seem to repeatedly migrate between beaches and underwater slopes until they are broken into small enough fragments that can be transported by currents to deeper areas and deposited out of reach of stormy waves (Chubarenko and Stepanova, 2017). The complex not resolved process of the particle's washing ashore has been replaced with the assumption that the washing ashore occurs when the coastal element of the mathematical model is reached (Liubartseva et al., 2018, Politikos et al., 2020).

In case the leading transport directions should be assessed - information valuable for understanding of the Baltic Sea dominant currents (Jedrasik and Kowalewski, 2019) might be important. Nevertheless, we find the issue important enough to implement the 
local models for better visualisation of potential pollution migration pathways that might influence the shoreline of the Baltic Sea in Latvia.

We propose the first numerical assessment of the wind and surface current driven transport in the Baltic Sea that is based on tracking the pathways that are daily released on the surface of the virtual Baltic Sea numerical model. The focus on the results along the shoreline of the Baltic Sea in Latvia providing its comparison with the other shorelines of the region is made. The virtual model of the Baltic Sea used in the numerical experiment is the same presented online in the demonstration service Present the present: FiMar for Web.

\section{Operational oceanographic service Present the present: FiMar for WEB}

Present the Present: FiMar for WEB is free operational downstream coastal service of oceanography and marine meteorology for the Baltic Sea. User may model the drift trajectories for objects of his interest in its virtual environment. Its functionality: 1) sea surface contour plots (wave height, water level, current velocity, water temperature, salinity, ice thickness, wind speed, air temperature, drift velocity), Figure 1; 2) the drift motion visualisation - wind \& surface current \& wave (Stokes drift) impact included - user initiated drift simulation of user selected floating objects starting at user selected time/location (1-hour temporal resolution), Figure 2;

3) sea surface vector-(direction-) plots (current, wave, wind, drift), Figure 2; 4) sea surface contour plots of the climatic anomalies (deviation from the climatic mean of the 15 years in the past) for 2 oceanographic parameters: a) sea surface temperature and b) water level. Climatic anomalies represent deviation of the sea surface temperature and water level in comparison with its climatic average in previous 15 years using 11 days frame that means 5 days around the date for the water level and 7 days frame ( 3 days around the date, respectively) for the sea surface temperature.

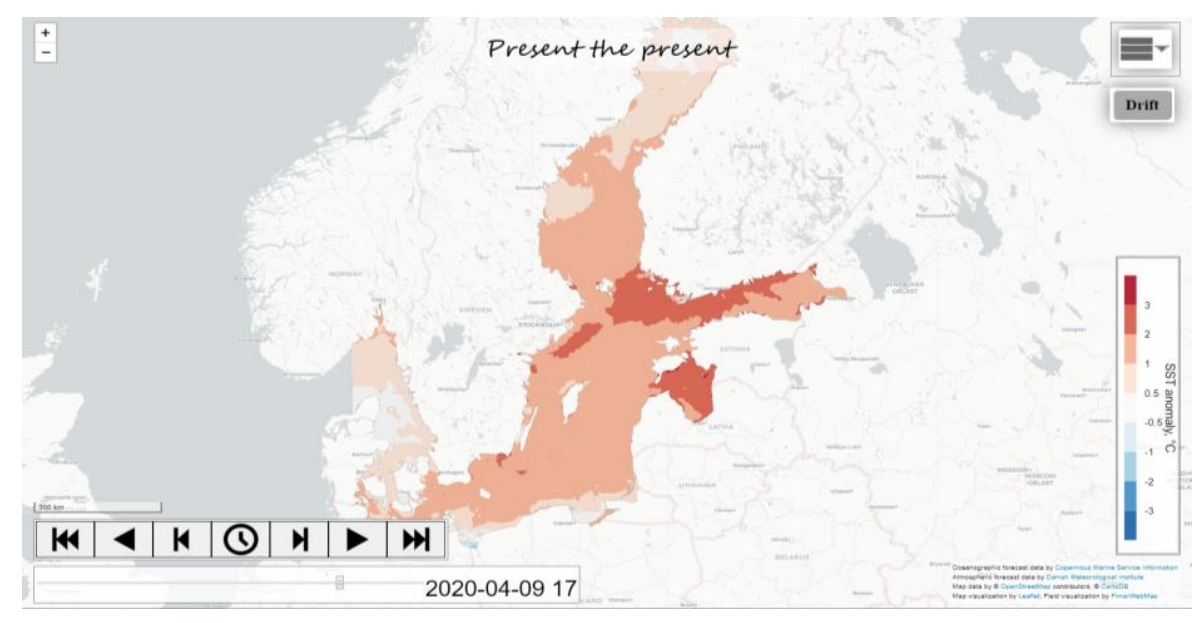

Figure 1. Sea surface temperature (SST) anomaly in the Baltic Sea on April 9th 2020 @ 17:00. 


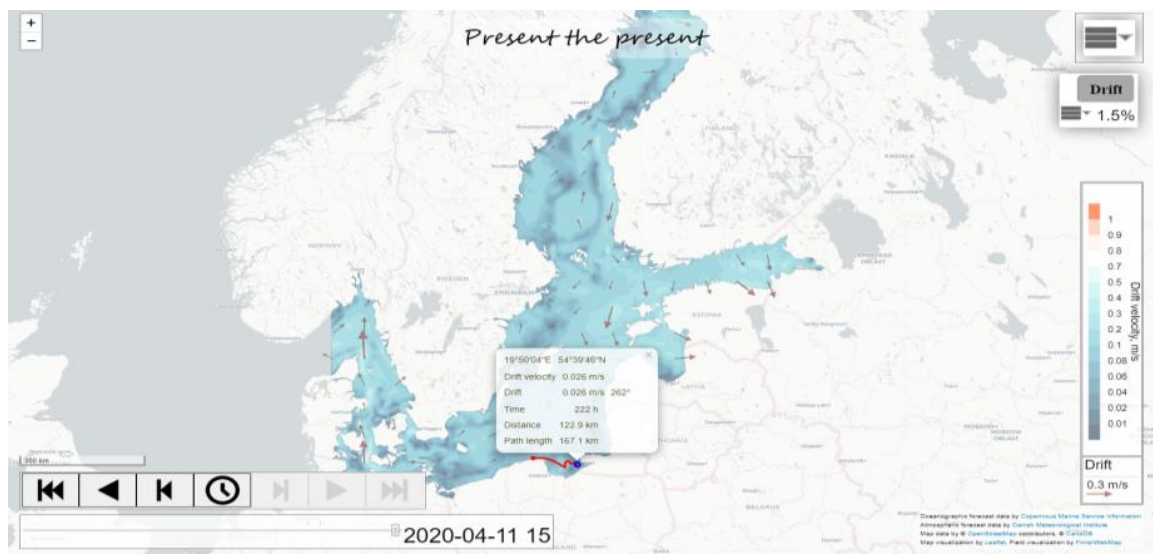

Figure 2. Example of drift velocity plot in Present the present: Fimar for Web service demonstration. Red line shows the modeled pathway of a drifting object 02.04.2020 @9:00 - assuming the wind factor 1.5\%.

\section{Numerical drift experiment}

The numerical study of tracing the particles (17 561 particles daily) that are released on the regular $5 \times 5 \mathrm{~km}$ grid on the surface of the Baltic Sea is performed. The experiment is done for time period: 2008 - 2018. Shoreline segments where washing ashore occurs are analysed in the numerical experiment. Particle is assumed to be washed ashore when it reaches the coastal mesh element in the system.

There are 4982 coastal mesh elements in the experiment. Its length varies from 0.5 $13.8 \mathrm{~km} .40$ main islands that might "catch" the released particles in the sea are included in the study. The finest coastal elements are in the shoreline of Latvia varying from 0.5 $6.0 \mathrm{~km}$. The average length of the coastal mesh elements is $1.2 \mathrm{~km}$ in shoreline of Latvia and $2.9 \mathrm{~km}$ in the whole system.

The motion of the particle on the sea surface is governed by two vectors - the wind velocity and the surface current. Wind factor $1.5 \%$ is used in the numerical experiment - wind velocity weighted with 0.015 is added to the current velocity with the weight $0.985=1-0.015$, the displacement of the particle with one hour time resolution is repeated until the end of the period or the condition that the coastal element is reached. The motion does not occur in case the particle is located inside the mesh element with an ice coverage according to Copernicus Marine Services data layer. The daily release of the particles continues including the regions covered by ice. Its motion according to above mentioned conditions is continued when ice layer has been melted. The main research questions addressed in the study: does the Baltic Sea shoreline of Latvia receives more particles than other shorelines in the model? Is there seasonality impact on the amount of the washed ashore particles observable? Where does the particles washed ashore in the Baltic Sea in Latvia come from? 


\section{Results of the numerical drift experiment}

The marine area taken into consideration in the numerical experiment is shown in Figure 2. It borders with the shoreline of 10 countries. The total length of the shoreline in the experiment is $14440 \mathrm{~km}$ (30\% of the shoreline refers to shoreline of 40 islands included in the experimental system). Table 1 shows how the total washed ashore particles are distributed among the shorelines of the virtual experimental system (shown in Figure 1). It offers overview - which countries have the highest and lowest total amounts of the total number of washed ashore particles in the experiment (column 2), shoreline length corresponding to each of countries (column 3) and the indicator intensity that shows does the country in total received amount is above or below an average per shoreline $\mathrm{km}$ (column 4).

Table 1. Numerical drift experiment result: distribution among countries, shoreline length and the accumulation intensity

$\begin{array}{rccc}\text { Washed ashore in } & \begin{array}{c}\text { Shoreline of the } \\ \text { country/washed ashore in } \\ \text { total, } \%\end{array} & \begin{array}{c}\text { Intensity } \\ \text { country/model } \\ \text { shoreline, } \%\end{array} & \begin{array}{c}\text { (relative to } \\ \text { average) }\end{array} \\ \text { Denmark } & 8.0 & 18.7 & 0.4 \\ \text { Germany } & 2.6 & 7.7 & 0.3 \\ \text { Poland } & 4.3 & 4.5 & 0.9 \\ \text { Russia } & 6.1 & 6.1 & 1.0 \\ \text { Lithuania } & 4.3 & 1.4 & 3.1 \\ \text { Latvia } & 9.3 & 3.5 & 2.7 \\ \text { Estonia } & 12.8 & 8.6 & 1.5 \\ \text { Finland } & 25.5 & 16.8 & 1.5 \\ \text { Sweden } & 25.8 & 29.6 & 0.9 \\ \text { Norway } & 1.2 & 3.2 & 0.4\end{array}$

Results in Table 1 indicate that Latvia and Lithuania are among 2 countries with the highest accumulation intensities relative to an average. Sweden is country with the longest shoreline in the region - almost $30 \%$ of the total shoreline length in the model. It receives (similarly to Finland) a quarter of the particles released in the experiment. At the same time, it is seen that Finland accumulation intensity is higher than that of Sweden.

The extremes for the islands in the Baltic sea are shown in Tables 2 and 3. 
Table 2. Top 3 islands with the highest total received amount of the particles in the experiment

$\begin{array}{lccc} & \begin{array}{c}\text { Washed ashore } \\ \text { on the island/in } \\ \text { total, \% }\end{array} & \begin{array}{c}\text { Shoreline of the island/model } \\ \text { shoreline, \% }\end{array} & \begin{array}{c}\text { Intensity } \\ \text { (relative to } \\ \text { average) }\end{array} \\ \text { Saaremaa (Estonia) } & 5.1 & 2.1 & 2.5 \\ \text { Gotland (Sweden) } & 3.7 & 1.9 & 1.9 \\ \text { Hiiumaa (Estonia) } & 2.7 & 1.3 & 2.2\end{array}$

Table 3. Top 3 islands with the highest intensity

$\begin{array}{lccc} & \begin{array}{c}\text { Washed ashore } \\ \text { on the island/in } \\ \text { total, \% }\end{array} & \begin{array}{c}\text { Shoreline of the } \\ \text { island/model shoreline, } \%\end{array} & \begin{array}{c}\text { Intensity } \\ \text { (relative to } \\ \text { average) }\end{array} \\ \begin{array}{l}\text { Kvarken (Finland) } \\ \begin{array}{l}\text { Island in Turku } \\ \text { Archipelago }\end{array}\end{array} & 1.3 & 0.4 & 3.5 \\ \begin{array}{l}\text { (Finland) } \\ \text { Saaremaa (Estonia) }\end{array} & 0.7 & 0.2 & 3.2 \\ \end{array}$

The smallest islands accounted in the virtual model have been Ruhnu island (Estonia) in the Gulf of Riga with the shoreline length $0.1 \%$ of the total receiving $0.2 \%$ of the washed ashore particles (intensity 2.0) and Kihnu island (Estonia) with the shoreline length $0.1 \%$ of the total receiving $0.2 \%$ of the washed ashore particles (intensity 1.8).

The least intensive washing ashore of the particles has been observed in the island Alnon near Swedish city Sundswall in the Bothnian bay - with almost 10 times less than average washed ashore particles (intensity 0.11 ).

It has been shown that Latvia and Lithuania shorelines are having higher than average loads of the particles in the experiment. There is higher accumulation intensity of the washed ashore particles in Finland than in Sweden. Finnish and Estonian islands are among those receiving the highest loads. The island receiving the least load relative to its shoreline length belongs to Sweden and it is in the western part of the Bothnian bay.

These results agree with the understanding of the dominant winds and currents in the region shown byJedrasik and Kowalewski (2019). It takes more detailed study to describe the characteristic features of the results of the numerical experiment in the whole area. The results in the shoreline of Latvia with the focus of its western part where the highest loads could be expected are analysed in detail.

Figure 3 illustrate that the highest accumulation intensity is found in Kurzeme shoreline of the Baltic Sea in summer and autumn. There are lower accumulation intensities in the shoreline of the Gulf of Riga - especially in its Kurzeme shore. The lowest accumulation intensities in the shoreline of the Gulf of Riga in Latvia are found in winter and autumn seasons, the highest - in spring. 


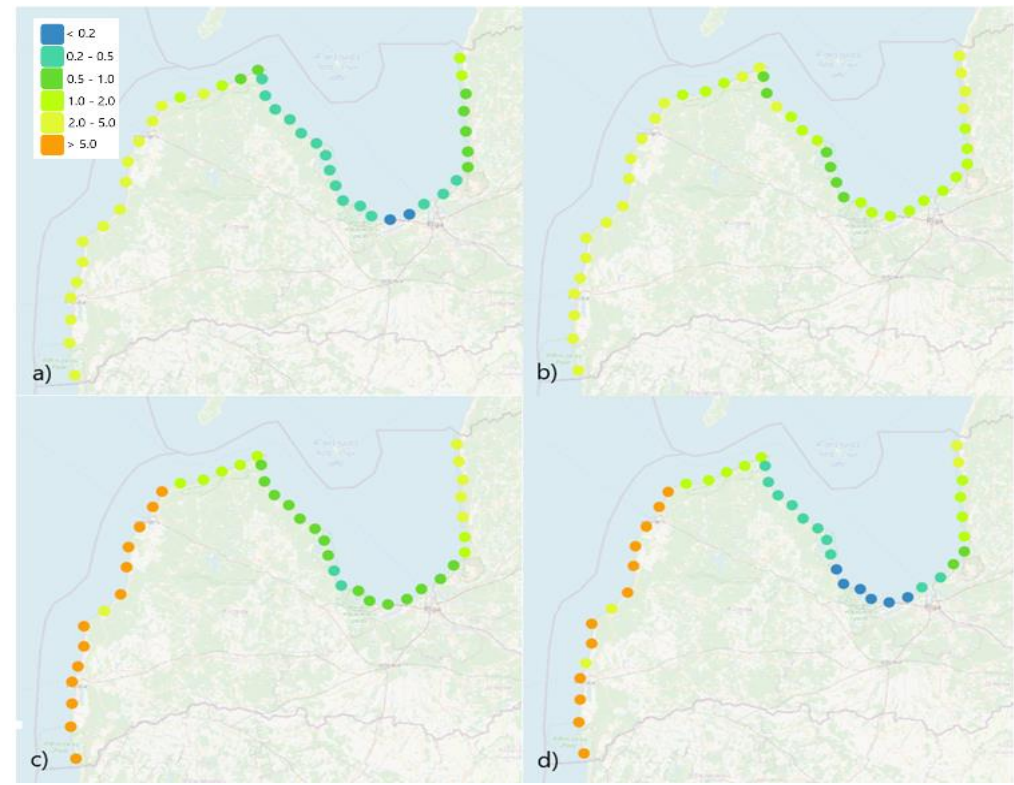

Figure 3. Accumulation intensity of washed ashore particles in the shoreline of Latvia in winter January, February, March (a), spring - April, May, June (b), summer - July, August, September (c), autumn - October, November, December (d). The accumulation intensity relative to $1 / 4$ the mean value in the whole period 2008-2018 per shoreline length is calculated. Base map from openstreetmap.org is used.

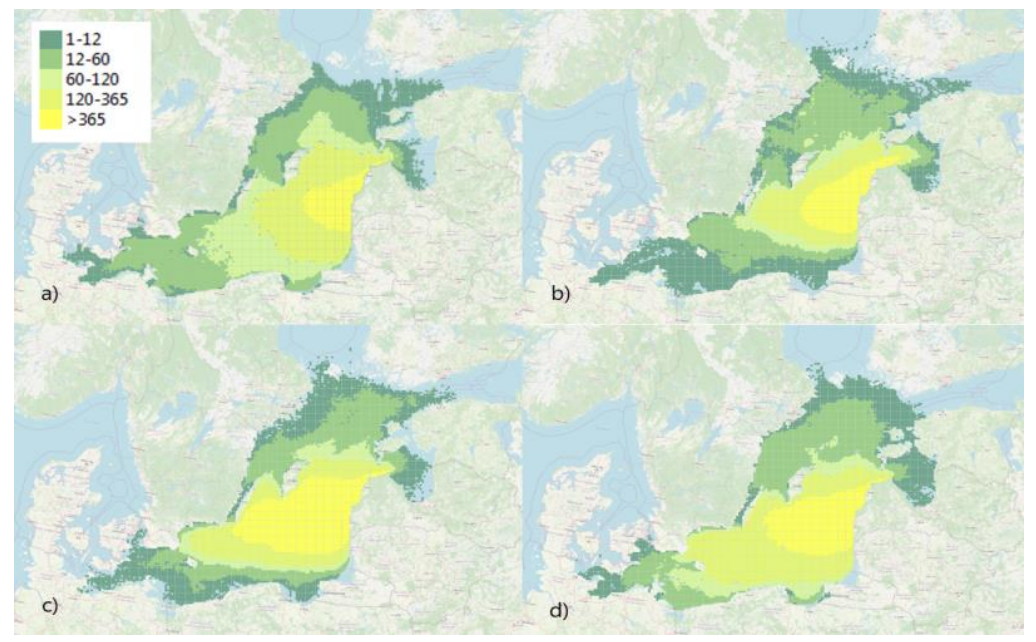

Figure 4. Number of particles in each $5 \times 5 \mathrm{~km}$ grid cell that are washed ashore on Nida-Cape Kolka shoreline during 2008-2018 in winter - January, February, March (a), spring - April, May, June (b), summer - July, August, September (c), autumn - October, November, December (d). Base map from openstreetmap.org is used.

Figure 4 shows where does the particles that are washed ashore in the Kurzeme shoreline of the Baltic Sea come from. It is shown that according to the proposed model 
- there are almost no particles washed ashore from the Gulfs of Bothnia and Finland in the shoreline of the Baltic Sea in Latvia. It is seen that the particles released in the Gulf of Parnu does not reach this shoreline as well.

An average time from the release of the particles to its washing ashore on NidaCape Kolka shoreline is 31 days. The median travel time until washing ashore is - 17 days in winter, 25 days - spring, 31 days - summer and 16 days - autumn in the experiment.

\section{Conclusions}

Numerical drift experiment on the surface of the virtual model of the Baltic Sea has shown that there are higher than average accumulation intensities in the shoreline of the Baltic Sea in Latvia expected in case the drifting object motion is governed by the surface current and wind (wind factor $1.5 \%$ ). The highest accumulation intensities could be found on the shoreline of the Baltic Sea in Kurzeme in summer and autumn seasons. The median travel time for the particles is between 16-31 days for the particles washed ashore on the Nida-Cape Kolka shoreline in the experiment. The lowest accumulation intensities are found in the Kurzeme shoreline of the Gulf of Riga.

\section{Acknowledgements}

Research has benefited from the support of the Latvian Academy of Sciences, project lzp-2018/1-0162 DRIMO - Drift Modelling for pollution reduction and safety in the Baltic Sea, 2018-2021.

\section{References}

Chubarenko, I., Stepanova, N. (2017). Microplastics in sea coastal zone: Lessons learned from the Baltic amber, Environmental Pollution, Vol. 224, pp. 243-254

Gewert, B., Ogonowski, M., Barth, A., MacLeod, M. (2017). Abundance and composition of near surface microplastics and plastic debris in the Stockholm Archipelago, Baltic Sea, Marine Pollution Bulletin, Vol.120, Issues 1-2, pp. 292-302

Hardesty, B. D., Vince, J. (2016). Plastic pollution challenges in marine and coastal environments: From local to global governance, Restoration Ecology, Vol. 25, Issue 1, pp. 123-128

Jedrasik, J., Kowalewski, M. (2019). Mean annual and seasonal circulation patterns and long-term variability of currents in the Baltic Sea, Journal of Marine Systems, Vol. 193, pp. 1-26

Liubartseva, S., Coppini, G., Lecci, R., Clementi, E. (2018). Tracking plastics in the Mediterranean: 2D Lagrangian model, Marine Pollution Bulletin, Vol. 129, Issue 1, pp. 151162

Politikos, D. V., Tsiaras, K., Papatheodorou, G., Anastasopoulou, A. (2020). Modeling of floating marine litter originated from the Eastern Ionian Sea: Transport, residence time and connectivity, Marine Pollution Bulletin, Vol. 150

Uotila, J. (2001). Observed and modelled sea-ice drift response to wind forcing in the northern Baltic Sea, Tellus A, Vol. 53, Issue 1, pp. 112-128

Villarrubia-Gómez, P., Cornell, S. E.,Fabres, J. (2018). Marine plastic pollution as a planetary boundary threat - The drifting piece in the sustainability puzzle, Marine Policy, Vol. 96, pp. 213-220

Received October 21, 2020, accepted November 13, 2020 